\title{
African star grass response to postemergence herbicides
}

\section{Resposta da grama estrela-africana a herbicidas aplicados em pós-emergência}

\author{
Alexandre Magno Brighenti ${ }^{* *}$ (D) Flávio Rodrigo Gandolfi Benites ${ }^{1}$ (D) Fausto Souza Sobrinho
}

${ }^{1}$ Empresa Brasileira de Pesquisa Agropecuária/EMBRAPA, Embrapa Gado de Leite, Juiz de Fora, MG, Brasil

*Corresponding author: alexandre.brighenti@embrapa.br

Received in November 19, 2018 and approved in February 15, 2019

\begin{abstract}
Cynodon nlemfuensis Vanderyst, commonly called African star grass, is excellent forage in pasture formation and herd feeding. However, little information is available regarding weed management in areas of star grasses. Two field experiments were carried out in 2017 and 2018 to evaluate the response of African star grass to postemergence herbicides. The treatments applied were as follows: 2,4-D (1,340.0 g ae ha-1); 2,4-D + picloram (720.0 $+192.0 \mathrm{~g}$ ae ha ${ }^{-1}+0.3 \% \mathrm{v} / \mathrm{v}$ nonionic surfactant); fluroxypyr + picloram $(80.0+80.0 \mathrm{~g}$ ae ha-1 $+0.3 \% \mathrm{v} / \mathrm{v}$ mineral oil); fluroxypyr + aminopyralid $\left(160.0+80.0 \mathrm{~g}\right.$ ae ha ${ }^{-1}+0.3 \% \mathrm{v} / \mathrm{v}$ mineral oil); fluroxypyr + triclopyr $(320.0+960.0 \mathrm{~g}$ ae ha-1 $+0.3 \%$ v/v mineral oil); bentazon (720.0 $\mathrm{g}$ ai ha-1 $+0.5 \% \mathrm{v} / \mathrm{v}$ mineral oil); imazapyr (25.0 $\mathrm{g}$ ai ha-1); monosodium methyl arsenate (MSMA) (1,440.0 $\mathrm{g}$ ai ha ${ }^{-1}+0.1 \% \mathrm{v} / \mathrm{v}$ nonionic surfactant); atrazine + S-metolachlor $\left(1,480.0+1,160.0 \mathrm{~g}\right.$ ai ha- $\left.{ }^{-1}\right)$; atrazine + tembotrione $(1,000.0+100.8 \mathrm{~g}$ ai $\mathrm{ha}^{-1}+0.3 \% \mathrm{v} / \mathrm{v}$ mineral oil) and a control without herbicide application. The most phytotoxic treatments for the African star grass plants were fluroxypyr + amininopyralid, fluroxypyr + triclopyr and atrazine + tembotrione. The dry matter yield of star grass plants was not reduced by the applications of 2,4-D, 2,4-D + picloram, bentazon, imazapyr, MSMA and atrazine + S-metolachlor. These herbicides can be considered potential practices in African star grass crop management.
\end{abstract}

Index terms: Chemical control; Cynodon nlemfuensis; forages; pastures; selectivity.

\section{RESUMO}

A grama estrela africana (Cynodon nlemfuensis Vanderyst) é considerada excelente forrageira. Contudo, há poucas informações disponíveis sobre o manejo de plantas daninhas em áreas de grama estrela. Dois experimentos foram realizados em 2017 e 2018 para avaliar a resposta da grama estrela africana a herbicidas pós-emergentes. Os tratamentos foram: 2,4-D (1.340,0 g ea ha-1), 2,4-D + picloram (720,0

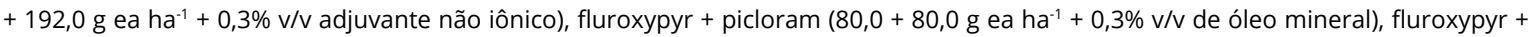

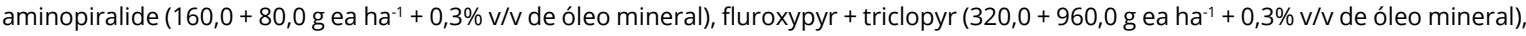
bentazon (720,0 $\mathrm{g}$ ia ha-1 $+0,5 \% \mathrm{v} / \mathrm{v}$ de óleo mineral), imazapyr (25,0 $\mathrm{g}$ ia ha-1), metano arseniato ácido monossódio (MSMA) (1.440,0 g ia ha-1 $+0,1 \%$ v/v adjuvante não iônico), atrazina + S-metolachlor $\left(1480,0+1.160,0 \mathrm{~g}\right.$ ia ha $\left.{ }^{-1}\right)$, atrazine + tembotrione $(1.000,0+100,8 \mathrm{~g}$ ia $\mathrm{ha}^{-1}+0,3 \% \mathrm{v} / \mathrm{v}$ óleo mineral) e a testemunha sem aplicação de herbicida. Os tratamentos mais fitototóxicos para grama estrela africana foram fluroxypyr + amininopiralide, fluroxypyr + triclopyr e atrazina + tembotrione. O rendimento de matéria seca das plantas de grama estrela-africana não foi prejudicado pela aplicação de 2,4-D, 2,4-D + picloram, bentazon, imazapyr, MSMA e atrazina + S-metolachlor. Esses herbicidas podem ser considerados tratamentos potenciais no manejo de pastagens formadas por grama estrela africana.

Termos para indexação: Controle químico; Cynodon nlemfuensis; forrageiras; pastagens; seletividade.

\section{INTRODUCTION}

The majority of Brazilian livestock cattle herds are supported by pastures as the main source of their food. Moreover, forage grasses established in tropical climates are suitable alternatives due to their high productivity potential and low cost of management (Pedreira, 2010).

Grasses of the genus Cynodon include several tropical forage species with capacity to feed ruminants (Amorim et al., 2017). The center of origin of these species is Africa where they present high productivity potential given the soil and climate conditions (Hanna; Sollenberger, 2007).

These species can be used for grazing or forage conservation (hay, silage or predrying) (Pedreira, 2010). The dry matter yield per hectare per year can reach 17.5 tons, with protein values ranging from $11 \%$ to $16 \%$ and $55 \%$ to $60 \%$ of digestibility (Vendramini; Mislevy, 2016).

Most likely, plants of Cynodon arrived in Brazil on ships from Africa that specialized in the slave trade (Pedreira, 2010). Studies on the differentiation between 
East African species have resulted in the following classification: Bermudian grasses (C. dactylon), which present rhizomes and stolons, and star grasses $(C$. plectostachyus; C. aethiopicus and C. nlemfuensis), which have only stolons (Benites; Souza Sobrinho; Vilela, 2016).

In terms of C. nlemfuensis Vanderyst, this species is adapted to the Brazilian climate and soil conditions. It has a $\mathrm{C}_{4}$ photosynthetic metabolism and, rapid growth and development, multiplying mainly by vegetative parts (Smith; Valenzuela, 2002). Plants are easily established as a result of the rapid regrowth of stolons, even when submitted to fire (Cook et al., 2005). According to Muniz et al. (2014), milk production in pastures of C. nlemfuensis can range from 15.2 to $18.5 \mathrm{~kg}$ of milk / cow / day.

Several species and cultivars are being researched by different public institutions and private companies to provide different alternatives to cattle growers. However, there is a lack of information regarding the behavior of African star grass in field conditions mainly related to weed management.

There are no recommendations and registered herbicides on the Brazilian Agriculture Ministry for the chemical control of weeds in star grass pastures.

The correct elimination of weeds has great importance in avoiding yield losses and low quality forage. In this context, studies that aim to determine the tolerance capacity of Cynodon species to herbicides will certainly provide support for integrated weed management in pastures and consequently have a greater impact on productivity and forage quality.

The objective of this study was to evaluate the response of African star grass to postemergence herbicides.

\section{MATERIAL E METHODS}

Two experiments were carried out under field conditions in Coronel Pacheco, Minas Gerais State, Brazil ( $21^{\circ} 32^{\prime} 51.42^{\prime \prime} \mathrm{S}$ and $43^{\circ} 15^{\prime} 39.82^{\prime \prime} \mathrm{W}-412 \mathrm{~m}$ altitude). The mean monthly air temperatures (maximum and minimum) and rainfall during the experimental periods are shown in Figure 1.

The treatments were as follows: $2,4-\mathrm{D}-\left(\right.$ Aminol $\left.^{\mathrm{TM}}\right)$ $\left(1,340.0 \mathrm{~g}^{\text {ae ha }}{ }^{-1}\right) ; 2,4-\mathrm{D}+$ picloram $\left(\right.$ Tordon $\left.^{\mathrm{TM}}\right)(720.0$ $+192.0 \mathrm{~g} \mathrm{ae} \mathrm{ha}^{-1}+0.3 \% \mathrm{v} / \mathrm{v}$ nonionic surfactant); fluroxypyr + picloram $\left(\right.$ Plenum $\left.^{\mathrm{TM}}\right)\left(80.0+80.0 \mathrm{~g} \mathrm{ae} \mathrm{ha}^{-1}+0.3 \% \mathrm{v} / \mathrm{v}\right.$ mineral oil); fluroxypyr + aminopyralid (Dominum ${ }^{\mathrm{TM}}$ ) $(160.0+80.0 \mathrm{~g}$ ae ha-1 $+0.3 \% \mathrm{v} / \mathrm{v}$ mineral oil $)$; fluroxypyr + triclopyr $\left(\right.$ Truper $\left.^{\mathrm{TM}}\right)\left(320.0+960.0 \mathrm{~g}^{2}\right.$ ae ha ${ }^{-1}+0.3 \% \mathrm{v} / \mathrm{v}$ mineral oil); bentazon (Basagran $\left.{ }^{\mathrm{TM}}\right)\left(720.0 \mathrm{~g}\right.$ ai ha ${ }^{-1}+0.5 \%$ v/v mineral oil); imazapyr (Kapina $\left.{ }^{\mathrm{TM}}\right) \quad\left(25.0 \mathrm{~g}_{\text {ai }} \mathrm{ha}^{-1}\right)$; monosodium methyl arsenate (MSMA) (Volcane ${ }^{\mathrm{TM}}$ ) $\left(1,440.0 \mathrm{~g}^{\text {ai ha }}{ }^{-1}+0.1 \% \mathrm{v} / \mathrm{v}\right.$ nonionic surfactant $)$; atrazine + S-metolachlor (Primestra Gold $\left.{ }^{\mathrm{TM}}\right)(1,480.0+1,160.0 \mathrm{~g}$ ai ha $\left.{ }^{-1}\right)$; atrazine + tembotrione $\left(\right.$ Gesaprim $^{\mathrm{TM}}+$ Soberan $\left.^{\mathrm{TM}}\right)$ $\left(1,000.0+100.8 \mathrm{~g}\right.$ ai ha $^{-1}+0.3 \% \mathrm{v} / \mathrm{v}$ mineral oil $)$ and a contol without herbicide application.

Four replications of each treatment were arranged according to a randomized complete block design.

Both experiments were installed on an area originally covered with African star grass pasture.

The soil of the experimental area is classified as fluvic cambisol and chemical analyses of the soil samples (0-20 cm depth) were as follows: $\mathrm{pH}\left(\mathrm{H}_{2} \mathrm{O}\right)=5.8, \mathrm{P}=79.4$ $\mathrm{mg} \mathrm{dm}{ }^{-3}, \mathrm{~K}=370 \mathrm{mg} \mathrm{dm}^{-3}, \mathrm{Ca}^{2+}=3.92 \mathrm{cmol}_{\mathrm{c}} \mathrm{dm}^{-3}, \mathrm{Mg}^{2+}=$ $1.5 \mathrm{cmol}_{\mathrm{c}} \mathrm{dm}^{-3}, \mathrm{Al}^{3+}=0.0 \mathrm{cmol}_{\mathrm{c}} \mathrm{dm}^{-3}, \mathrm{H}+\mathrm{Al}=5.2 \mathrm{cmol}_{\mathrm{c}}$ $\mathrm{dm}^{-3}$, CTC $(\mathrm{T})=11.7 \mathrm{cmol}_{\mathrm{c}} \mathrm{dm}^{-3}$ and $\mathrm{V}=55 \%$.

One cut of the aerial parts of the plants were performed one month before herbicide application to standardize plant stands and avoid overgrowth of the forage.

The application of the treatments was performed on November 1, 2017 (experiment 1), and April 9, 2018 (experiment 2), when African star grass plant height was approximately $0.30 \mathrm{~m}$.

All herbicide treatments were applied using a back pack sprayer (Herbicat - Catanduva, São Paulo, Brazil). The spray boom (2.0 m length) contained four flat nozzles (Magno ADGA 110.02), spaced $0.5 \mathrm{~m}$ apart, delivering a spray volume equivalent to $150 \mathrm{~L} \mathrm{ha}^{-1}$. The climatic conditions (climate averages) during the herbicide application were as follows: experiment 1 (temperature $25^{\circ} \mathrm{C}$, relative humidity $80 \%$ and wind speed $2.5 \mathrm{~m} \mathrm{~s}^{-1}$ ) and experiment 2 (temperature $22{ }^{\circ} \mathrm{C}$, relative humidity $71 \%$ and wind speed $\left.2.0 \mathrm{~m} \mathrm{~s}^{-1}\right)$.

The percentages of phytotoxicity were evaluated at 7, 14, 21 and 28 days after herbicide application (DAA), where zero corresponded to no symptoms of phytotoxicity on African star grass plants and $100 \%$ total death of the plants (Sociedade Brasileira da Ciência das Plantas Daninhas - SBCPD, 1995).

Plant heights were measured with a graduated ruler at 23 and 35 days after the application of the treatments. African star grass aerial parts were collected at 35 DAA, simulating the rest period of 3-5 weeks recommended for Cynodon species, when it is possible to obtain high digestibility and crude protein forage (Fontaneli et al., 2012). Plants were cut within a quadrat $(0.5 \times 0.5 \mathrm{~m})$ at the soil surface and placed in kraft paper bags. The material was dried in a forced-air ventilation oven at $65^{\circ} \mathrm{C}$ for $72 \mathrm{~h}$ until reaching a constant mass and subsequent weighing on a graduated scale. The dry matter weights were converted to $\mathrm{kg} \mathrm{ha}^{-1}$. 


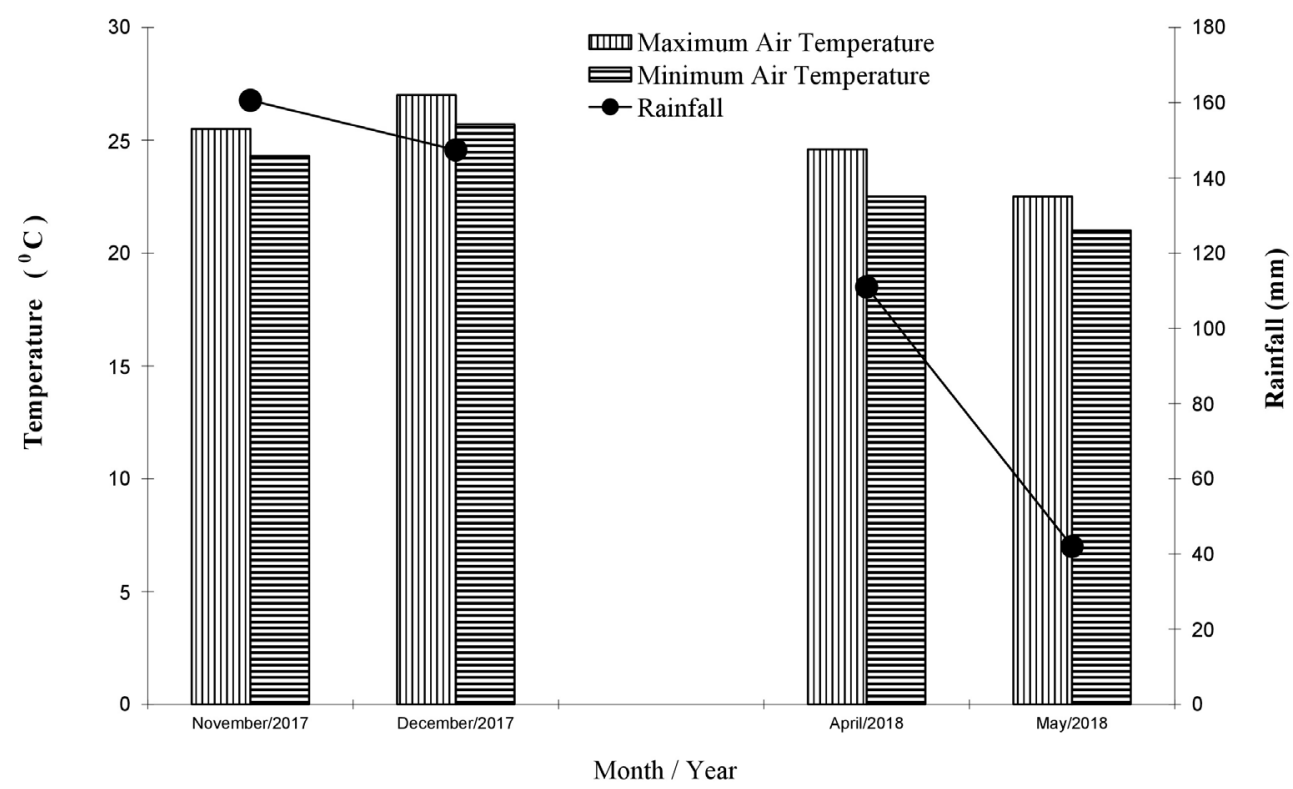

Figure 1: Mean monthly air temperatures (maximum and minimum) and rainfall during the experimental periods (Experiment 1: November and December - 2017; experiment 2: April and May - 2018).

The percentage of phytotoxicity was normalized by square root transformation of $(x+1)$ to perform the analysis of variance (ANOVA) tests. Data were subjected to ANOVA and mean values were compared using the Scott-Knott test $(P \leq 0.05)$. Statistical analyses were performed using statistical and genetic analysis system (SAEG) software (Ribeiro Júnior, 2001; Ribeiro Júnior, 2013) for both experiments.

\section{RESULTS AND DISCUSSION}

Treatments with 2,4-D and 2,4-D + picloram resulted in low values of phytotoxicity $(0 \%-5.5 \%)$ on African star grass plants (Table 1). There were no longer any visual symptoms of injury at 21 and 28 DAA. The same herbicides 2,4-D and 2,4-D + picloram were applied on an African star grass pasture to control Vernonia polyanthes and Desmodium incanum (Krenchinski et al., 2015). Both traits caused low levels of phytotoxicity ranging from 0.0 to 3.2 , respectively, at 14 DAA. Similarly, phytotoxicity symptoms were acceptable with the application of 2,4-D (2,010 $\mathrm{g}$ ai ha $\left.\mathrm{ha}^{-1}\right)$ on Bermuda grass $(C$. dactylon), with plant recovery at 50 days after herbicide application (Chritoffoleti; Aranda, 2001). The herbicides 2,4-D and 2,4 D + picloram were applied on Bermuda grass (C. dactylon) at doses of $670 \mathrm{~g} \mathrm{ae} \mathrm{ha}^{-1}$ and $480+128 \mathrm{~g}$ ae ha $^{-1}$, respectively (Maciel et al., 2017). The herbicides were selective for Bermuda grass and provided efficient control of Hydrocotyle bonariensis weed. Janak et al. (2015) verified that the application of $2,4-\mathrm{D}(0.8 \mathrm{~kg}$ $\mathrm{ha}^{-1}$ ) on Tifton 85 Bermuda grass (C. dactylon) exhibited no necrosis, growth reduction or yield reduction at any time.

The three treatments in which fluroxypyr was a component of the formulated mixture showed symptoms of injury at the initial evaluations, persisting up to 21 DAA (Table 1). Fluroxypyr + aminopyralid and fluroxypyr + triclopyr were the most phytotoxic. Fluroxypyr + aminopyralid was also applied on African star grass, being the most phytotoxic treatment with values ranging from $5.7 \%$ to $19.0 \%$ at 21 DAA (Krenchinski et al., 2015). The herbicides fluroxypyr and fluroxypyr + picloram were applied to Coastal Bermuda grass $(C$. dactylon) plants; causing reductions on the total dry matter yield by an average of $25 \%$ with $0.42 \mathrm{~kg} \mathrm{ha}^{-1}$ fluroxypyr, and by $20 \%$ with picloram $\left(0.188 \mathrm{~kg} \mathrm{ha}^{-1}\right)+$ fluroxypyr $\left(0.188 \mathrm{~kg} \mathrm{ha}^{-1}\right)$ (Butler; Muir, 2006).

Bentazon and imazapyr were selective for African star grass plants (Tables 1). For both experiments, no visual symptoms were observed at any evaluation, except with imazapyr (2.5\%) at 7 DAA (experiment 2). Plant recovery was detected and the symptoms disappeared at 14 DAA. Imazapyr (Kapina ${ }^{\mathrm{TM}}$ and Kapina Plus ${ }^{\mathrm{TM}}$ ) was applied on C. dactylon to control Cyperus flavus and C. rotundus 
(Maciel et al., 2013). Doses ranging from 18.7 to $56.2 \mathrm{~g}$ ai ha ${ }^{-1}$ provided excellent weed control and satisfactory selectivity for $C$. dactylon.

The percentage values of phytotoxicity reached $25.0 \%$ and $18.7 \%$ at 7 DAA for MSMA in experiments 1 and 2, respectively (Table 1). The characteristic symptom was chlorosis on African star grass leaves. However, there was plant recovery, and no visual symptom of injury was detected at 28 DAA for both experiments. The formulated mixture of MSMA + diuron was applied during late postemergence in an African star grass pasture (Alves; Alves; Soler, 2012). This mixture was selective for African star grass and efficient in controlling Brachiaria seedlings, allowing forage formation in areas of degraded pastures of Brachiaria. Sequential applications of MSMA (2.8 kg ai ha ${ }^{-1}$ ) controlled yellow nutsedge (Cyperus esculentus) greater than $80 \%$ when nutsedge was in Bermuda grass (C. dactylon) (Blum; Isgrigg; Yelverton, 2000).

The formulated mixture of atrazine + S-metolachlor was also selective for African star grass. No visual symptom of injury was observed in any evaluation in experiment 1 (Table 1). In experiment 2, a slight yellowing symptom was detected at 7 DAA, but there was no longer any symptom of injury on plants for the next evaluation.

The atrazine + tembotrione mixture was the most phytotoxic treatment among all herbicides, with percentage values above $51 \%$ during the first evaluation for both experiments (Table 1). The characteristic symptom on African star grass plants was bleaching (albinism), or leaf whitening. Although the albinism disappeared over time, a slight symptom remained at 28 DAA.

Tembotrione was applied to hybrid Bermuda grass (C. dactylon $\mathrm{x}$ C. transvaalensis) plants (Elmore et al., 2011). The herbicide caused high values of bleaching measurements and great reductions in total chlorophyll, lutein, and xanthophyll cycle pigment concentrations.

Regarding the second evaluation of plant height, all treatments provided values statistically equal to the control, except MSMA and atrazine + tembotrione (experiment 1) (Table 2). In experiment 2, 2,4-D, 2,4-D + picloram, fluroxypyr + picloram, bentazon and imazapyr did not cause reduction on plant height (Table 2).

Dry matter production was not affected by the application of treatments 2,4-D, 2,4-D + picloram, bentazon, imazapyr, MSMA and atrazine + S-metolachlor in experiments 1 and 2 (Table 2). Applications of these treatments did not affect African star grass forage yield due to its tolerance. These results indicate that 2,4-D, 2,4-D + picloram, bentazon, imazapyr, MSMA and atrazine $+\mathrm{S}$-metolachlor applied at these rates and at appropriate timings would be useful tools for weed management programs in African star grass production systems.

Table 1: Percentage of phytotoxicity on African star grass plants at 7 (P7), 14 (P14), 21 (P21) and 28 (P28) days after application of treatments.

\begin{tabular}{|c|c|c|c|c|c|c|c|c|c|}
\hline \multirow{2}{*}{ Treatments } & \multirow{2}{*}{ Doses $\left(g\right.$ ha-1 $\left.^{-1}\right)$} & \multicolumn{4}{|c|}{ Experiment 1} & \multicolumn{4}{|c|}{ Experiment 2} \\
\hline & & P7 & P14 & P21 & P28 & P7 & P14 & P21 & P28 \\
\hline $2,4-D$ & $1,340.0$ & $0.0 \mathrm{G}^{1}$ & $0.0 \mathrm{~F}$ & $0.0 \mathrm{~F}$ & $0.0 \mathrm{C}$ & 0.01 & $0.0 \mathrm{G}$ & $0.0 \mathrm{E}$ & $0.0 \mathrm{~B}$ \\
\hline 2,4-D + Picloram & $720.0+192.0$ & $4.3 \mathrm{~F}$ & $2.6 \mathrm{E}$ & $0.0 \mathrm{~F}$ & $0.0 \mathrm{C}$ & $5.5 \mathrm{~F}$ & $3.5 \mathrm{E}$ & $0.0 \mathrm{E}$ & $0.0 \mathrm{~B}$ \\
\hline Fluroxypyr + Picloram & $80.0+80.0$ & $5.0 \mathrm{E}$ & $2.3 \mathrm{E}$ & $1.0 \mathrm{E}$ & $0.0 \mathrm{C}$ & $11.0 \mathrm{D}$ & $5.7 \mathrm{D}$ & $1.5 \mathrm{D}$ & $0.0 \mathrm{~B}$ \\
\hline Fluroxypyr + Aminopyralid & $160.0+80.0$ & $19.6 \mathrm{C}$ & $30.6 \mathrm{~B}$ & $19.3 \mathrm{~B}$ & $11.6 \mathrm{~A}$ & $20.5 B$ & $15.5 \mathrm{C}$ & $5.7 \mathrm{C}$ & $0.0 \mathrm{~B}$ \\
\hline Fluroxypyr + Triclopyr & $320.0+960.0$ & $8.3 \mathrm{D}$ & $6.6 \mathrm{D}$ & $2.3 \mathrm{D}$ & $0.0 \mathrm{C}$ & $8.5 \mathrm{E}$ & $23.5 \mathrm{~B}$ & $11.0 \mathrm{~B}$ & $0.0 \mathrm{~B}$ \\
\hline Bentazon & 720.0 & $0.0 \mathrm{G}$ & $0.0 \mathrm{~F}$ & $0.0 \mathrm{~F}$ & $0.0 \mathrm{C}$ & 0.01 & $0.0 \mathrm{G}$ & $0.0 \mathrm{E}$ & $0.0 \mathrm{~B}$ \\
\hline Imazapyr & 25.0 & $0.0 \mathrm{G}$ & $0.0 \mathrm{~F}$ & $0.0 \mathrm{~F}$ & $0.0 \mathrm{C}$ & $2.5 \mathrm{H}$ & $0.0 \mathrm{G}$ & $0.0 \mathrm{E}$ & $0.0 \mathrm{~B}$ \\
\hline MSMA & $1,440.0$ & $25.0 \mathrm{~B}$ & $15.3 \mathrm{C}$ & $9.0 \mathrm{C}$ & $0.0 \mathrm{C}$ & $18.7 \mathrm{C}$ & $2.5 \mathrm{~F}$ & $0.0 \mathrm{E}$ & $0.0 \mathrm{~B}$ \\
\hline Atrazine + S-metolachlor & $1,480.0+1,160.0$ & $0.0 \mathrm{G}$ & $0.0 \mathrm{~F}$ & $0.0 \mathrm{~F}$ & $0.0 \mathrm{C}$ & $4.5 \mathrm{G}$ & $0.0 \mathrm{G}$ & $0.0 \mathrm{E}$ & $0.0 \mathrm{~B}$ \\
\hline Atrazine + Tembotrione & $1,000.0+100.8$ & $55.6 \mathrm{~A}$ & $61.3 \mathrm{~A}$ & $41.3 \mathrm{~A}$ & $10.3 \mathrm{~B}$ & $51.2 \mathrm{~A}$ & $89.5 \mathrm{~A}$ & $73.5 \mathrm{~A}$ & $25.0 \mathrm{~A}$ \\
\hline Control & - & $0.0 \mathrm{G}$ & $0.0 \mathrm{~F}$ & $0.0 \mathrm{~F}$ & $0.0 \mathrm{C}$ & 0.01 & $0.0 \mathrm{G}$ & $0.0 \mathrm{E}$ & $0.0 \mathrm{~B}$ \\
\hline Coefficient of Variation & - & 2.3 & 3.4 & 3.5 & 2.4 & 3.1 & 3.0 & 4.1 & 1.7 \\
\hline
\end{tabular}

${ }^{1}$ Mean values followed by different letters were grouped into different clusters according to Scott-Knott method. 
Table 2: Plant height $(\mathrm{cm})$ at $23 \mathrm{DAA}(\mathrm{H} 1)$ and $35 \mathrm{DAA}(\mathrm{H} 2)$, and dry matter weight (DMW) $\left(\mathrm{kg} \mathrm{ha}^{-1}\right)$.

\begin{tabular}{|c|c|c|c|c|c|c|c|}
\hline \multirow{2}{*}{ Treatments } & \multirow{2}{*}{ oses $\left(g_{\text {ha-1 }}\right.$ ) } & \multicolumn{3}{|c|}{ Experiment 1} & \multicolumn{3}{|c|}{ Experiment 2} \\
\hline & & $\mathrm{H} 1$ & $\mathrm{H} 2$ & DMW & $\mathrm{H} 1$ & $\mathrm{H} 2$ & DMW \\
\hline $2,4-\mathrm{D}$ & $1,340.0$ & $69.2 \mathrm{~B}$ & $82.3 \mathrm{~A}$ & $5,808.1 \mathrm{~A}$ & $60.7 \mathrm{~B}$ & $85.5 \mathrm{~B}$ & $11,897.5 \mathrm{~A}$ \\
\hline 2,4-D + Picloram & $720.0+192.0$ & $70.8 \mathrm{~A}$ & $84.0 \mathrm{~A}$ & $5,857.1 \mathrm{~A}$ & $51.2 \mathrm{C}$ & $88.7 \mathrm{~A}$ & $11,939.9 \mathrm{~A}$ \\
\hline Fluroxypyr + Picloram & $80.0+80.0$ & $61.6 \mathrm{C}$ & $83.6 \mathrm{~A}$ & $4,281.6 \mathrm{~B}$ & $42.2 \mathrm{D}$ & $86.5 \mathrm{~B}$ & $9,674.2$ B \\
\hline Fluroxypyr + Aminopyralid & $160.0+80.0$ & $52.3 \mathrm{D}$ & $83.3 \mathrm{~A}$ & $3,377.8 \mathrm{~B}$ & $35.7 \mathrm{E}$ & $82.0 \mathrm{C}$ & $6,561.6 \mathrm{C}$ \\
\hline Fluroxypyr + Triclopyr & $320.0+960.0$ & $51.8 \mathrm{D}$ & $82.0 \mathrm{~A}$ & 3,983.3 B & $34.7 \mathrm{E}$ & $81,5 \mathrm{C}$ & $5,762.3 \mathrm{C}$ \\
\hline Bentazon & 720.0 & $70.1 \mathrm{~B}$ & $84.6 \mathrm{~A}$ & $5,444.0 \mathrm{~A}$ & $64.0 \mathrm{~A}$ & $86.5 \mathrm{~B}$ & $11,158.2 \mathrm{~A}$ \\
\hline Imazapyr & 25.0 & $71.1 \mathrm{~A}$ & $84.0 \mathrm{~A}$ & $5,445.0 \mathrm{~A}$ & $62.5 \mathrm{~B}$ & $86.0 \mathrm{~B}$ & $12,915.7 \mathrm{~A}$ \\
\hline MSMA & $1,440.0$ & $61.3 \mathrm{C}$ & $73.3 \mathrm{~B}$ & $5,065.5 \mathrm{~A}$ & $52.5 \mathrm{C}$ & $83.0 \mathrm{C}$ & $11,957.2 \mathrm{~A}$ \\
\hline Atrazine + S-metolachlor & $1,480.0+1,160.0$ & $70.8 \mathrm{~A}$ & $83.6 \mathrm{~A}$ & $5,525.6 \mathrm{~A}$ & $64.5 \mathrm{~A}$ & $83.0 \mathrm{C}$ & $11,930.1 \mathrm{~A}$ \\
\hline Atrazine +Tembotrione & $1,000.0+100.8$ & $50.8 \mathrm{D}$ & $62.0 \mathrm{C}$ & $2,307.5 \mathrm{C}$ & $30.5 \mathrm{~F}$ & $51.5 \mathrm{D}$ & $5,105.9 \mathrm{C}$ \\
\hline Control & - & $71.0 \mathrm{~A}$ & $84.0 \mathrm{~A}$ & $5,176.4 \mathrm{~A}$ & $64.2 \mathrm{~A}$ & $85.7 \mathrm{~B}$ & $11,198.1 \mathrm{~A}$ \\
\hline Coefficient of Variation & - & 1.1 & 2.0 & 10.1 & 2.5 & 1.2 & 10.5 \\
\hline
\end{tabular}

${ }^{1}$ Mean values followed by different letters were grouped into different clusters according to Scott-Knott method.

\section{CONCLUSIONS}

The most phytotoxic treatments for the African star grass plants were fluroxypyr + amininopyralid, fluroxypyr + triclopyr and atrazine + tembotrione. The dry matter yield of African star grass plants was not reduced by the applications of 2,4-D, 2,4-D + picloram, bentazon, imazapyr, MSMA and atrazine + S-metolachlor. These herbicides can be considered potential practices in African star grass crop management.

\section{REFERENCES}

ALVES, S. J.; ALVES, R. M. L.; SOLER, J. A. Avaliação de herbicidas para o estabelecimento de grama estrela por mudas com raiz em pastagens degradadas de braquiária. Ambiência, 8(3):895-900, 2012.

AMORIM, D. S. et al. Caraterização e restrições de forrageiras indicadas para diferentes espécies de animais de produção Revista Eletrônica Científica da UERGS, 3(1):215-237, 2017.

BENITES, F. R. G.; SOUZA SOBRINHO, F.; VILELA, D. A contribuição do gênero Cynodon para a pecuária de leite. In: VILELA, D. et al. (Eds.). Pecuária de Leite no Brasil. Brasília, DF: Embrapa, 2016, p.147-166.

BLUM, R. R.; ISGRIGG, J.; YELVERTON, F. H. Purple (Cyperus rotundus) and Yellow nutsedge (C. esculentus) control in Bermuda grass (Cynodon dactylon) turf. Weed Technology, 14(2):357-365, 2000.
BUTLER, T. J.; MUIR, J. P. Coastal Bermuda grass (Cynodon dactylon) yield response to various herbicides. Weed Technology, 20(1):95-100, 2006.

COOK, B. G. et al. Tropical Forages: An interactive selection tool. (CD-ROM) (CSIRO, DPI\&F (QId), CIAT and ILRI: Brisbane, Qld. 2005.

CHRISTOFFOLETI, P.J.; ARANDA, A. N. Seletividade de herbicidas a cinco tipos de gramas. Planta Daninha, 19(2):273-278, 2001.

ELMORE, M. T. et al. Response of hybrid Bermuda grass (Cynodon dactylon x C.transvaalensis) to three HPPDinhibitors. Weed Science, 59(4):458-463, 2011.

FONTANELI, R. S. et al. Gramíneas Forrageiras Penenes de Verão. In: FONTANELI, R. S.; SANTOS, H. P.; FONTANELI, R. S. Forrageiras para integração lavoura-pecuária-floresta na Região Sul-Brasileira. 2.ed. Brasília-DF. Embrapa, p.247-284, 2012.

HANNA, W. W.; SOLLENBERGER, L. E. Tropical and subtropical grasses. In: BARNES, R. F. (Ed.) Forages: The science of grassland agriculture. 6 ed. Ames. Blackwell, p.245-255, 2007.

JANAK, T. W. et al. Use of selected herbicides and application methods for tolerance to Tifton 85 Bermuda grass [Cynodon dactylon (L.) Pers.]. American Journal of Experimental Agriculture, 8(5):289-298, 2015. 
KRENCHINSKI, F. H. et al. Application rates and herbicide in weed control in pasture. Revista Brasileira de Herbicidas, 14(4):271-279, 2015.

MACIEL, C. D. G. et al. Seletividade e eficácia dos herbicidas Kapina ${ }^{\circledR}$ e Kapina Plus ${ }^{\circledR}$ no controle de tiririca em gramas bermuda e esmeralda. Revista Brasileira de Herbicidas, 12(1):39-46, 2013.

MACIEL, C. D. G. et al. Eficiência de misturas em tanques de herbicidas no controle de erva-capitão em grama bermuda. Journal of Agronomic Sciences, 6(2):134-140, 2017.

MUNIZ, M. S. et al. Pastagens para produção leiteira. Caderno de Ciências Agrárias, 6(2):153-166, 2014.

PEDREIRA, C. G. S. Gênero Cynodon. In: FONSECA, D. M.; MARTUSCELLO, J. A. Plantas Forrageiras. Viçosa, MG. Editora UFV, p.78-130, 2010.
RIBEIRO JÚNIOR, J. I. Análises estatísticas no SAEG. Editora UFV, Viçosa: 2001, 301p.

RIBEIRO JÚNIOR, J. I. Análises estatísticas no Excel: Guia prático. Editora UFV, Viçosa: 2013. 311p.

SOCIEDADE BRASILEIRA DA CIÊNCIA DAS PLANTAS DANINHAS - SBCPD. Procedimentos para instalação e análise de experimentos com herbicidas. Sociedade Brasileira da Ciência das Plantas Daninhas. Londrina, PR. 1995. 42p.

SMITH, J.; VALENZUELA, H. Stargrass. Cooperative Extension Service, College of Agriculture and Human Resources. University of Hawaii, Manoa, USA. 2002. 3p.

VENDRAMINI, J.; MISLEVY, P. Stargrass. In: VENDRAMINI, J. (Eds). Florida forage handbook. University of Florida / IFAS Extension (SS-AGR-62), Florida, Estados Unidos, p.3033, 2016. 